\title{
Josefina Bañales Receives Emerging Scholar Best Article Award, 2021
}

\author{
Roger J. R. Levesque ${ }^{1}$
}

Received: 15 October 2021 / Accepted: 15 October 2021 / Published online: 24 October 2021

(C) The Author(s), under exclusive licence to Springer Science+Business Media, LLC, part of Springer Nature 2021

The editors of the Journal of Youth and Adolescence are very pleased to announce the 2021 recipient of its Emerging Scholar Best Article Award. This award goes to the article's lead author, who must be an "emerging scholar" (i.e., an untenured researcher, such as a graduate student, postdoctoral scholar, research scientist, or assistant professor) at the time their manuscript was accepted. The recipient of the award is selected by editorial board members who evaluate a volume's manuscripts on the basis of their innovative and substantive contributions to the empirical understanding of adolescence. In addition to receiving the recognition from colleagues, the winner receives a financial award generously provided by Springer, the journal's publisher.

The 2021 winner is Josefina Bañales, for her entitled "The Development of Ethnic-Racial Identity Process and Its Relation to Civic Beliefs among Latinx and Black American Adolescents" (Bañales et al. 2020). Dr. Bañales is an Assistant Professor in the Community and Prevention Research Area at the University of Illinois, Chicago (UIC). Her research examines how youth develop beliefs, feelings, and actions that challenge racism (i.e., youth critical racial consciousness development). Her co-authors were Adam J. Hoffman (now at Cornell University) Deborah Rivas-Drake (University of Michigan) and Robert J. Jagers (Collaborative for Academic, Social and Emotional Learning).

Her article notes that, despite associations between ethnic-racial identity processes and positive psychosocial outcomes among adolescents, limited empirical research investigated longitudinal associations between these processes and civic beliefs. To address this gap in the literature, her research examined how two important dimensions of ethnic-racial identity-exploration and resolution-changed across the middle school years predicted civic beliefs

Roger J. R. Levesque

rlevesqu@indiana.edu

1 Journal of Youth and Adolescencehttps://www.springer.com/ journal/10964 among adolescents. Participants included 400 Latinx $(\mathrm{n}=$ $121 ; 47.1 \%$ girls $)$ and Black American $(n=279 ; 52.0 \%$ girls) adolescents in the 6th $(\mathrm{n}=210), 7$ th $(\mathrm{n}=113)$ and 8 th Grades $(n=74)$. The study revealed that neither initial levels nor changes in ethnic-racial identity exploration predicted civic beliefs across four time-points of the study, or across two years of middle school. The findings were quite different for identity resolution. Adolescents who demonstrated greater increases in ethnic-racial identity resolution across two years of middle school were likely to have greater civic beliefs by the end of the two years, as compared to adolescents who had smaller increases in resolution. The findings suggest that adolescents who have an increasingly clear sense of their ethnic-racial selves may have greater access to cognitive and socioemotional resources that promote their development of beliefs on the need to advance the well-being of their communities.

The journal's editors view receiving the award as a considerably distinctive accomplishment. The journal publishes 12 issues per year, each typically containing about 16 manuscripts, as they have since the award was established 10 years ago (Levesque, 2011). In addition, it is notable that, every year, fewer and fewer first authors are emerging scholars. Although fewer emerging scholars qualify to be considered, this shift in authorship has not reduced the competitiveness of the award. In fact, these developments actually make the process even more competitive for emerging scholars, as they have increased competition to get published in the first place (see Levesque, 2017, 2018, 2019, 2020).

As we celebrate this award, it also is important to recognize the other truly outstanding articles deemed the best in each of the journal's other issues. Several of those articles focused on dimensions of parenting and family life (Rodríguez-Meirinhos et al., 2020; Thomas et al., 2020; Baudat et al., 2020; Wang et al., 2020). Some focused on peers (Laninga-Wijnen et al., 2020; Lessard et al., 2020; Busching \& Krahé, 2020). Others examined intricacies of coping, maturation and risk taking (McCuish et al., 2020; Rabinowitz et al., 2020; Duell \& Steinberg, 2020) as well as schooling as 
sites for interventions (Dawes et al., 2020; Olivier et al., 2020). For those of you who have a knack for details, know that there is an extra article, as one of the issues had a tie.

On behalf of the journal's editorial board, I would like to congratulate this year's recipient and her colleague. Their recognition comes at a remarkable time in the growth of our journal and field and highlight the need to consider and take seriously the intricacies of youth's engagement in societal changes.

\section{Compliance with Ethical Standards}

Conflict of Interest The authors declare no competing interests.

Publisher's note Springer Nature remains neutral with regard to jurisdictional claims in published maps and institutional affiliations.

\section{References}

Bañales, J., Hoffman, A. J., \& Rivas-Drake, D, et al. (2020). The development of ethnic-racial identity process and its relation to civic beliefs among Latinx and Black American adolescents. Journal of Youth and Adolescence, 49, 2495-2508. https://doi. org/10.1007/s10964-020-01254-6.

Baudat, S., Van Petegem, S., \& Antonietti, J. P, et al. (2020). Developmental changes in secrecy during middle adolescence: links with alcohol use and perceived controlling parenting. Journal of Youth and Adolescence, 49, 1583-1600. https://doi. org/10.1007/s10964-020-01281-3.

Busching, R., \& Krahé, B. (2020). With a little help from their peers: the impact of classmates on adolescents' development of prosocial behavior. Journal of Youth and Adolescence, 49, 1849-1863. https://doi.org/10.1007/s10964-020-01260-8.

Dawes, M., Farmer, T., \& Hamm, J, et al. (2020). Creating supportive contexts for early adolescents during the first year of middle school: impact of a developmentally responsive multi-component intervention. Journal of Youth and Adolescence, 49, 1447-1463. https://doi.org/10.1007/s10964-019-01156-2.

Duell, N., \& Steinberg, L. (2020). Differential correlates of positive and negative risk taking in adolescence. Journal of Youth and Adolescence, 49, 1162-1178. https://doi.org/10.1007/s10964-020-01237-7.

Laninga-Wijnen, L., Steglich, C., \& Harakeh, Z, et al. (2020). The role of prosocial and aggressive popularity norm combinations in prosocial and aggressive friendship processes. Journal of Youth and Adolescence, 49, 645-663. https://doi.org/10.1007/s10964019-01088-x.

Levesque, R. J. R. (2011). Emerging scholar best article award, 2011. Journal of Youth and Adolescence, 40, 1565-1567.

Levesque, R. J. R. (2017). Emerging scholar best article award, 2017. Journal of Youth and Adolescence, 46, 2500-2501.

Levesque, R. J. R. (2018). Emerging scholar best article award, 2018. Journal of Youth and Adolescence, 47, 2637-2638.

Levesque, R. J. R. (2019). Emerging scholar best article award, 2019. Journal of Youth and Adolescence, 48, 2331-2332.

Levesque, R. J. R. (2020). Anna Vannucii receives emerging scholar best article award, 2020. Journal of Youth and Adolescence, 49, 2407-2408.

Lessard, L. M., Watson, R. J., \& Puhl, R. M. (2020). Bias-based bullying and school adjustment among sexual and gender minority adolescents: the role of Gay-Straight Alliances. Journal of Youth and Adolescence, 49, 1094-1109. https://doi.org/10.1007/ s10964-020-01205-1.

McCuish, E., Lussier, P., \& Rocque, M. (2020). Maturation beyond age: interrelationships among psychosocial, adult role, and identity maturation and their implications for desistance from crime. Journal of Youth and Adolescence, 49, 479-493. https:// doi.org/10.1007/s10964-019-01178-w.

Olivier, E., Morin, A. J. S., \& Langlois, J, et al. (2020). Internalizing and externalizing behavior problems and student engagement in elementary and secondary school students. Journal of Youth and Adolescence, 49, 2327-2346. https://doi.org/10.1007/s10964020-01295-x.

Rabinowitz, J. A., Powell, T., \& Sadler, R, et al. (2020). Neighborhood profiles and associations with coping behaviors among lowincome youth. Journal of Youth and Adolescence, 49, 494-505. https://doi.org/10.1007/s10964-019-01176-y.

Rodríguez-Meirinhos, A., Vansteenkiste, M., \& Soenens, B., et al. (2020). When is parental monitoring effective? A person-centered analysis of the role of autonomy-supportive and psychologically controlling parenting in referred and non-referred adolescents. Journal of Youth and Adolescence, 49, 352-368. https://doi.org/ 10.1007/s10964-019-01151-7.

Thomas, K. J., Rodrigues, H., \& de Oliveira, R. T, et al. (2020). What predicts pre-adolescent compliance with family rules? A longitudinal analysis of parental discipline, procedural justice, and legitimacy evaluations. Journal of Youth and Adolescence, 49, 936-950. https://doi.org/10.1007/s10964-019-01158-0.

Wang, D., Choi, J. K., \& Shin, J. (2020). Long-term neighborhood effects on adolescent outcomes: mediated through adverse childhood experiences and parenting stress. Journal of Youth and Adolescence, 49, 2160-2173. https://doi.org/10.1007/s10964020-01305-y. 